Bioeduca: Journal of Biology Education
$\frac{\text { http://iournal.walisongo.ac.id/index.php/bioeduca }}{\text { ISSN 2714-8009 (print), 2715-7490 (online) }}$
Bolume 2, Nomor 2, Tahun 2020
Hal. $67-72$

\title{
Analisis Permasalahan Guru Dan Siswa Terhadap Model Pembelajaran Graphic Organizer dan Berpikir Kreatif Terhadap Hasil Belajar
}

\author{
Sumartijah $^{1^{*}}$, Elsje Theodora Maasawet ${ }^{2}$, Didimus Tanah Boleng ${ }^{3}$ \\ ${ }_{1,2,3}$ Pendidikan Biologi, Universitas Mulawarman \\ *Email: emmasawet@gmail.com
}

\begin{tabular}{|c|c|}
\hline Informasi Artikel & ABSTRAK \\
\hline $\begin{array}{l}\text { Submit: } 21-06-2020 \\
\text { Diterima: } 05-08-2020 \\
\text { Dipublikasikan: } 11-10-2020\end{array}$ & $\begin{array}{l}\text { Fungsi pendidikan adalah menyiapkan peserta didik melalui } \\
\text { proses yang berlangsung sebelum peserta didik itu siap bekerja } \\
\text { di kehidupan nyata. Tujuan penelitian adalah mengetahui } \\
\text { permasalahan guru dan siswa pada model pembelajaran } \\
\text { Graphic Organizer terhadap berpikir kreatif dan hasil belajar } \\
\text { siswa. Populasi dalam penelitian ini adalah siswa siswi kelas X } \\
\text { berjumlah } 60 \text { orang. Penelitian dilakukan di SMAN } 8 \text { Samarinda. } \\
\text { Pengumpulan data menggunakan angket dan wawancara. } \\
\text { Metode penelitian menggunakan penelitian eksperimen semu } \\
\text { (Quasi Experiment). Hasil angket yang dilakukan terhadap siswa } \\
\text { siswi menunjukkan bahwa } 50,00 \% \text { masih kurang dalam berpikir } \\
\text { kreatif pada saat proses pembelaran biologi di kelas. Sedangkan } \\
60,00 \% \text { hasil belajar siswa masih dibawah rata-rata, Perangkat } \\
\text { pembelajaran yang dimiliki kurang kurang lengkap. } \\
\text { Kata kunci: analisis permasalahan; hasil belajar; model } \\
\text { pembelajaran; metode penelitian. }\end{array}$ \\
\hline Penerbit & ABSTRACT \\
\hline $\begin{array}{l}\text { Program Studi Pendidikan } \\
\text { Biologi, Fakultas Sains dan } \\
\text { Teknologi, UIN Walisongo } \\
\text { Semarang }\end{array}$ & $\begin{array}{l}\text { The function of education is to prepare students through a } \\
\text { process that takes place before the students are ready to work in } \\
\text { real life. The research objective was to determine the problems } \\
\text { of teachers and students in the Graphic Organizer learning model } \\
\text { on creative thinking and student learning outcomes. The pupils in } \\
\text { this study were } 60 \text { class X students. The research was conducted } \\
\text { at SMAN } 8 \text { Samarinda. Data collection using questionnaires and } \\
\text { interviews. The research method uses quasi-experimental } \\
\text { research (Quasi Experiment). The results of questionnaires } \\
\text { conducted on female students showed that } 50.00 \% \text { were still } \\
\text { lacking in creative thinking during the biology learning process in } \\
\text { the classroom. While } 60.00 \% \text { of student learning outcomes are } \\
\text { still below average, the learning tools that are owned are } \\
\text { incomplete. } \\
\text { Keywords: learning models; learning outcomes; problem } \\
\text { analysis; research methods. }\end{array}$ \\
\hline
\end{tabular}

Copyright $(22020$, Bioeduca: Journal of Biology Education

\section{PENDAHULUAN}

Menurut Hamalik, (2012) Fungsi pendidikan adalah menyiapkan peserta didik melalui proses yang berlangsung sebelum peserta didik itu siap bekerja dikehidupan nyata. Strategi pelaksanaan pendidikan dilakukan dalam bentuk kegiatan bimbingan, pengajaran, dan latihan. 
Salah satu upaya untuk meningkatkan mutu pendidikan adalah dengan cara memperbaiki sistem pembelajaran. Seorang guru yang profesional sebelum mengajar harus menyiapkan perangkat pembelajaran terlebih dahulu. Guru dapat mengevaluasi cara mengajar dengan teraplikasinya penyusunan perangkat pembelajaran dalam proses pembelajaran di dalam kelas. Profesionalisme seorang guru dapat ditingkatkan dengan perangkat pembelajaran. Dengan demikian, perangkat pembelajaran tidak hanya sebagai kelengkapan administrasi, tetapi juga sebagai media peningkatan profesionalisme.

Model pembelajaran adalah suatu perencanaan atau suatu pola yang digunakan sebagai pedoman dapat digunakan dalam merencanakan pembelajaran dikelas atau pembelajaran dalam tutorial (Trianto, 2011). Menurut Dimyati (2013) hasil belajar merupakan hasil dari suatu interaksi tindak belajar dan tindak mengajar. Dari sisi guru tindak mengajar diakhiri dengan proses evaluasi hasil belajar. Dari sisi siswa, hasil belajar merupakan berakhirnya penggal dan puncak proses belajar.

Graphic organizers merupakan suatu bentuk visualisasi yang menyampaikan pesan atau informasi melalui penampilan non bahasa (Orlich, et all, 2010; Marzano, 2007). Penyampaian pesan dengan menggabungkan teks dengan gambar diasumsikan dapat memberikan kemudahan bagi pelajar karena visualisasi yang merepresentsikan informasi dapat segera diterima dan dipahami oleh pelajar, Pengetahuan yang direpresentasikan melalui bantuan gambar akan lebih mudah dan cepat dipahami oleh para pelajar.

Pembelajaran sains, khususnya dalam pembelajaran biologi, guru dapat menggunakan model pembelajaran Graphic organizers sebagai alat dalam membantu guru dalam memberikan pemahaman materi biologi bagi siswanya. Menurut Tsui \& Treagust (2013) materi biologi secara umum dapat dikelompokkan menjadi empat level, yaitu: 1) level makroskopis; 2) level mikroskopis; 3) level submikroskopis; dan 4) level simbolik. Materi biologi baik dari level makroskopis sampai dengan level simbolik dapat disampaikan dengan menggunakan Graphic organizers untuk memudahkan pelajar dalam memahami materi tersebut.

Guru dituntut untuk dapat menguasai perangkat pembelajaran yang sesuai dengan kebutuhan siswa, serta dapat mengoptimalkan perangkat pembelajaran sehingga hasil belajar siswa meningkat.

Perangkat pembelajaran dapat dijadikan sebagai acuan dalam proses pembelajaran, selain itu dapat dijadikan sebagai media peningkatan profesionalisme. Sebagaimana guru profesional adalah yang memenuhi standar kompetensi meliputi penguasaan ilmu pengetahuan, keterampilan, dan sikap. Selain itu dengan mengembangkan perangkat pembelajaran yang dimiliki akan memberikan kemampuan bagi guru untuk mengembangkan teknik mengajar dan menjadi dasar untuk merancang perangkat yang lebih baik.

Hasil observasi dan wawancara mengenai analisis kebutuhan di SMA Negeri 8 Samarinda diperoleh informasi bahwa sebagaian besar guru biologi kurang memahami tentang model pembelajaran sesuai materi dan penyesuaian dalam membuat perangkat pembelajaran. Hal ini dikarenakan masih terbatasnya sumber 
daya yang dapat dipergunakan dan dimanfaatkan oleh guru untuk pembelajaran. Sebanyak $60,00 \%$ menyatakan bahwa pemahaman guru biologi tentang perangkat pembelajaran dan model pembelajaran itu masih kurang. Seharusnya pemahaman guru tentang perangkat pembelajaran dan komponen-komponennya sangat dikuasai guru karena baik buruknya hasil perangkat pembelajaran yang disusun bergantung pada pemahaman dan kreatifitas guru untuk mengefektifkan pembelajaran di kelas (Alfiah, 2017).

Pembelajaran Biologi menekankan pada pemberian pengalaman secara langsung dikembangkan dengan proses ilmiah yang dapat mendorong siswa dapat berkreatif dan aktif pada saat proses pembelajaran, dalam hal ini adalah kegiatan praktikum yang dilakukan baik di dalam maupun di luar kelas. Secara umum pembelajaran biologi dibangun atas dasar produk ilmiah, proses ilmiah, dan sikap ilmiah.

\section{METODE PENELITIAN}

Penelitian ini merupakan penelitian eksprimen semu (Quasi Experiment) yang mempunyai kelompok kontrol dan kelompok perlakuan (Sugiyono, 2009). Penelitian eksperimen merupakan penelitian yang sistematis, logis, dan teliti (Arikunto, 2013). Penelitian menggunakan model pembelajaran Graphic organizers dan berpikir kreatif. Populasi pada penelitian ini yaitu siswa kelas X SMA Negeri 8 Samarinda. Variabel independen/ bebas adalah Model Pembelajaran Graphic organizers, Varibel dependen/ terikat adalah motivasi dan hasil belajar siswa kelas $\mathrm{X}$.

\section{HASIL PENELITIAN DAN PEMBAHASAN}

Graphic organizers merupakan alat yang efektif dan efisien dalam pembelajaran (McKnight, 2013). Pertama, dapat memfokuskan siswa pada iformasi-informasi kunci yang penting. Kedua, kita dapat belajar dari gambar yang merupakan representasi visual berupa materi baru baik dalam bentuk teks maupun gambar. Ketiga, materi akan tersusun dengan kebutuhan pelajar. Keempat, dapat menstimulus siswa untuk bepikir kritis dan kreatif karena sajian gambar yang disajikan akan merangsang siswa untuk belajar lebih aktif. Kelima, dapat dijadikan sebagai alat penilaian yang akan memberikan alternatif cara penilaian bagi dunia pendidikan selain tes konvensional.

Berpikir kreatif adalah kemampuan individu untuk memikirkan apa yang telah dipikirkan semua orang, sehingga individu tersebut mampu mengerjakan apa yang belum pernah dikerjakan oleh semua orang. Terkadang berpikir kreatif terletak pada inovasi yang membantu diri sendiri untuk mengerjakan hal-hal lama dengan cara yang baru.

Identifikasi masalah dilakukan berdasarkan quesioner observasi yang mengenai permasalahan yang dihadapi guru dan siswa di sekolah. Berikut permasalahan yang dihadapi guru di sekolah: Sebagian besar guru menggunakan metode konvensional/ceramah, perangkat pembelajaran yang dimiliki oleh guru tidak lengkap, model pembelajaran kurang bervariasi dan kurang adanya sosialiasasi atau pelatihan untuk guru. 
Berikut permasalahan yang dihadapi siswa di sekolah: Sebagaian besar siswa cenderung kurang aktif di kelas, siswa kurang termotivasi dalam belajar, hasil belajar sebagaian besar kurang mencapai standar yang ditentukan dan keterampilan berpikir kretaif dan kritis masih kurang.

Belajar bukan hanya merupakan proses mengingat sesuatu, tetapi belajar merupakan suatu proses membentuk makna agar terbentuk pengetahuan baru. Graphic organizer merupakan suatu bentuk visualisasi yang menyampaikan pesan atau informasi melalui penampilan non bahasa (Orlich, et al, 2010; Marzano, 2007). Penyampaian pesan dengan menggabungkan teks dengan gambar diasumsikan dapat memberikan kemudahan bagi pelajar karena visualisasi yang merepresentasikan informasi dapat segera diterima dan dipahami oleh pelajar. Pengetahuan yang direpresentasikan melalui bantuan gambar akan lebih mudah dan cepat dipahami oleh para pelajar.

Hasil belajar siswa merupakan salah satu tujuan dari pembelajaran di sekolah, untuk itu seorang guru perlu mengetahui dan mempelajari beberapa metode mengajar, serta dipraktikan saat mengajar. Perbedaan hasil belajar dipengaruhi oleh perlakuan saat proses pembelajaran berlangsung. Keberhasilan proses pembelajarn dapat dilihat dari kemampuan guru dalam mengembangakn model-model pembelajaran yang bervariasi (Rochmayatun, et al, 2017).

Hasil belajar sebagai salah satu indikator pencapaian tujuan pembelajaran di kelas tidak terlepas dari faktor-faktor yang mempengaruhi hasil belajar itu sendiri. Menurut Sugihartono (2007) menyebutkan faktor-faktor yang mempengaruhi hasil belajar sebagai berikut: 1. Faktor internal adalah faktor yang ada dalam diri individu yang sedang belajar. Faktor internal meliputi faktor jasmani dan faktor psikologis. 2 . Faktor eksternal adalah faktor yang ada diluar individu, faktor eksternal meliputi faktor keluarga, faktor sekolah, faktor masyarakat.

Berdasarkan hasil observasi dan wawancara kepada guru biologi bahwasanya $60 \%$ hasil belajar siswa masih dibawah rata-rata KKM yang telah ditentukan dan 50\% siswa dalam berpikir kreatif. Hal ini menjadikan guru harus melakukan kajian ulang dan harus melakukan perubahan dalam sistem pembelajaran di kelas.

Peneliti melakukan inovasi dengan model pembelajaran Graphic organizer dan berpikir kreatif terhadap hasil belajar supaya dapat membantu guru dalam memberikan materi biologi di kelas dan dapat membantu siswa lebih berpikir kreatif sehingga hasil belajar lebih baik dibandingkan sebelumnya. Stimulasi untuk analisis berpikir dapat diberikan selama kegiatan belajar mengajar di kelas. Rangsangan tersebut, termasuk alat pembelajaran dan metode pembelajaran. Penggunaan alat pembelajaran yang kurang variatif dapat berdampak pada kurangnya kemampuan berpikir analitis siswa (Luk luatun , 2019).

Menurut Djamarah dalam Syaiful Bahri (2012), "prestasi adalah hasil dari suatu kegiatan yang telah dikerjakan, atau diciptakan secara individu maupun secara kelompok". Pendapat ini berarti prestasi tidak akan pernah dihasilkan apabila seseorang tidak melakukan kegiatan. Hasil belajar atau prestasi belajar adalah suatu hasil yang telah dicapai oleh siswa setelah melakukan kegiatan belajar. Oleh karena 
itu prestasi belajar bukan ukuran, tetapi dapat diukur setelah melakukan kegiatan belajar. Keberhasilan seseorang dalam mengikuti program pembelajaran dapat dilihat dari prestasi belajar seseorang tersebut.

\section{SIMPULAN DAN SARAN}

Berdasarkan penelitian simpulan yang didapatkan yaitu sebagai berikut : Guru kurang berinovasi dalam membuat perangkat dan model pembelajaran, Guru masih menggunakan model konvensional yaitu ceramah, Sebagaian besar siswa kurang tertarik dan cenderung kurang aktif dalam proses pembelajaran di kelas, Hasil belajar kognitif siswa masih dibawah rata-rata. Perlu adanya solusi untuk membantu guru biologi dalam menerapkan model pembelajaran di kelas.

Berdasarkan penelitian yang dilakukan diatas, maka disarankan: sebaiknya guru biologi mencari refrensi dan mengikuti workshop tentang inovasi pembelajaran, Guru enggunakan model pembelajaran yang inovatif dan menarik, Guru biologi harus dapat berkreatifitas dalam memanfatkan media pembelajaran dan laboratorium untuk praktikum serta alam sekitar.

\section{UCAPAN TERIMA KASIH}

Terimakasih kepada lbu Dr.Elsje Theodora Maasawet, M.Pd dan Bapak Dr Didimus Tanah Boleng,M.Pd selaku pembimbing yang telah memberikan ilmunya dan waktunya. Terimakasih kepada keluarga besar SMAN 8 Samarinda yang telah membantu dalam wawancara dan kegiatan penelitian. Terimakasih kepada keluarga saya yang selalu mensuport dan memberikan doa.

\section{RUJUKAN}

Arikunto, S. (2013). Prosedur Penelitian: Suatu Pendekatan Praktik. Jakarta:Rineka Cipta.

Dimyati. (2013). Belajar dan Pembelajaran. Jakarta:Rineka Cipta.

Djamarah, Syaiful bahri. (2012). Psikologi Belajar. Jakarta: Rineka Cipta.

Hamalik, Oemar. (2011). Proses Belajar Mengajar. Jakarta . PT Bumi Aksara.

Lukluatun Nisa, Siti Mukhlishoh Setyawati, Bunga Ihda Norra. (2019). Increasing analytical thinking skills through a popup booklet development with digestive system. Journal of Physics: Conference Series.1241.iop publishing

Masril. (2011). Pengembangan Model pembelajaran Fisika Berbasis Graphic Organizer Melalui Belajar Kooperatif Tipe STAD. Jurnal Penelitian Pembelajaran Fisika1, 1-17.

McKnight, K. S. (2013) The elementary Teacher's Big Book of Graphic Organizerz: 100+ Ready-to-Use Organizers that Help Kids Learn Language Arts, Scince, Social Studies, and More!. San Fransisco: John Willey \& sons, Inc.

Orlich, D.C., Harder, R.J., Callahan, R. C., Trevisan, M.S \& Brown, A.H. (2010). Teaching Strategis, A Guide to Effective Instruction, 9ed. Boston: Wadswordth Cegage Learning.

Robert j marzano. (2007). The Art And Science Of Teaching. ASCD : Alexandria.

Rochmayatun, Miswari, Bunga Ihda N. (2017). Pengaruh Penggunaan Model Pembelajaran Kooperatif Tipe NHT (Numbered Head Together) Berbasis Media 
Tebak Gambar Terhadap Hasil Belajar Siswa Kelas XI Materi Sistem Ekskresi Di Man Kendal Tahun Pelajaran 2016/2017. Skripsi. UIN Walisongo Semarang. Siti alfiah, Mlswari, Bunga Ihda norra. (2018). Pengembangan media pembelajaran biologi berbasis permainan biodakon materi vertebrata kelas X MA Matholi'ul Huda Troso Jepara. Skripsi. UIN Walisongo Semarang

Sugihartono, dkk. (2007). Faktor-faktor mempengaruhi hasil belajar_Psikologi Pendidikan. Yogyakarya:UNY Pers.

Sugiyono. (2009). Metode Penelitian Pendidikan Pendekatan Kuantitatif, Kualitatif, dan $R \& D$, Bandung : Alfabeta.

Trianto. (2011). Model - Model Pembelajaran Inovatif Berorientasi Konstruktivstik. Jakarta: Prestasi Pustaka.

Tsui, C. \& Treagust, D.F. (2013). Introduction to Multiple Representations: Their Importance in Biology and Biological Education. In Tsui, C. \& Treagust, D. F. (Ed), Multiple Representations in Biological Education (pp. 3-18). London: Springer. 